\title{
Comparison of Broiler Chicken Behavioral Response in Differing Closed House Length throughout the Dry
}

\section{Season}

\author{
Winda Virdya Sitorus, Dwi Sunarti, Teysar Adi Sarjana* \\ Poultry Production Laboratory, Faculty of Animal and Agricultural Sciences, Universitas Diponegoro \\ *Email :teysaradisarjana@lecturer.undip.ac.id
}

\begin{abstract}
This study aims at comparing the behavioral response of broiler chickens maintained at different closed house length in the dry season. 600 broiler chickens with an average weight of $41.30 \pm 2.68 \mathrm{~g}$ and two closed house units, each with a length of $60 \mathrm{~m}$ and $120 \mathrm{~m}$ having a capacity of 11,000 and 22,000 were used. Heat production is represented through eating, walking, and stretching behaviors. This research observed drinking and resting behaviors of the chickens. This is descriptive research conducted in the starter period (14 days old) of the chickens. The results show that the resting and stretching behaviors of chickens residing in the $120 \mathrm{~m}$ closed house are higher than those in the $60 \mathrm{~m}$ closed house; no difference is observed in drinking behaviors. The average frequency and duration of walking and eating of chickens residing in the $120 \mathrm{~m}$ closed house are lower than those in the $60 \mathrm{~m}$ closed house indicating that broilers reduce the frequency and duration of walking and eating. The findings show that chickens raised in longer cages will show behavioral responses representing an increase of heat loss and a reduction of heat production.
\end{abstract}

Keywords: broiler chicken behavior, heat loss, heat production, dry season, closed house

Received 24 June 2019 | Revised 30 June 2019| Accepted 1 August 2019

\section{Introduction}

Closed house is a closed cage used to remove excess heat and gases such as carbon dioxide and ammonia. The dry season causes livestock to be prone to heat stress, including broiler chickens. Therefore, a closed house is used to minimize changes in the macro-climate, especially during the dry season. Differences in air temperature, humidity, air flow (ventilation), and litter can increase ammonia levels in the cage (Sulaibah et al., 2019). Poultry is classified as homeothermic (warm-blooded) animals with specific characteristics such as skin without sweat 
glands and mostly covered in fur. This causes difficulty in disposing body heat into the environment (Tamzil, 2014). Ammonia gas produced from broiler manure will then be discharged out to be exchanged with oxygen gas to help metabolize the body of the chicken. From this, it can be estimated that the highest ammonia levels are located in zones furthest from the inlet.

The length of a closed house is adjusted according to the number of chickens. Longer enclosures will generally produce higher ammonia levels because of a large amount of nitrogen and materials contained in the excreta present in the cage. Ammonia microclimate will also increase according to a cage size.

Behaviors representing broiler chicken heat loss include drinking, resting, and stretching patterns, while heat production is represented by eating and walking patterns. Heat dissipation will cause stressed animals to show several characteristics such as anxiety, larger amounts of water drinking, smaller amounts of food consumption, and wings flapping on the cage floor (Tamzil, 2014). If there is a decrease in ambient temperature, they will try to produce heat in a number of ways, such as moving and eating less. This will negatively impact their performance (Lembey, 2011).

Ammonia increase and a high cage temperature will result in respiratory irritation of the broiler chickens which causes heat loss inefficiency and a decrease in their appetite (Austic, 1985). Chickens that are kept in an intensive system will spend more time eating because their activities are limited to the cage. Cages with closed systems affect the spread of ammonia which will impact the health of broiler chickens (Haryadi, 1995). The high ammonia level will cause respiratory infection and less food consumption. Therefore, chickens raised in different cages will provide different behavioral responses.

Broiler chickens attempt to dissipate heat from their bodies by reducing food consumption; this is intended to maintain body temperature so as not to exceed the threshold (May and Lott, 1992). In addition, chickens will usually move a lot of muscles by walking to produce mechanical heat to counteract cold stress. Zhou et al. (2004) state that chickens affected by heat stress will experience difficulty in breathing, reduced appetite, less rest, and will perch under the cage. This study aims at comparing the behavioral response of broiler chickens kept in different closed house length during the dry season. 


\section{Methods}

\subsection{Research Materials}

The materials consist of broiler chickens with an average DOC weight of $41.30 \pm 2.68$ $\mathrm{g} /$ chicken, 4 units of camera to record chicken behavior, 4 units of tripods to support the camera, and food. 2 closed house cages were used with different specification: cage A measuring $60 \mathrm{~m}$ with a capacity of 11,000 and cage B measuring $120 \mathrm{~m}$ with a capacity of 22,000 placed in 4 different zones.

\subsection{Research Method}

This research was conducted descriptively. The observation was conducted to chickens aged 14 days every 6 hours $(07.00,13.00,20.00,02.00)$ for 10 minutes in each zone.

\subsection{Data Analysis}

This study uses a descriptive analysis method. According to Sugiyono (2010), descriptive analysis is a statistical analysis used to describe the data obtained. The data is quantitative data presented with numbers.

Table 1. Ammonia average level in each closed house

\begin{tabular}{cc}
\hline Closed House & Ammonia Level \\
\hline $60 \mathrm{~m}$ & $2.96 \mathrm{ppm}$ \\
$120 \mathrm{~m}$ & $4.65 \mathrm{ppm}$ \\
\hline
\end{tabular}

Table 2. Microclimate average in each closed house

\begin{tabular}{ccccc}
\hline Time & Closed House & \multicolumn{3}{c}{ Microclimate } \\
\hline & & $\begin{array}{c}\text { Temperature } \\
\left({ }^{0} \mathrm{C}\right)\end{array}$ & THI & Humidity(\%) \\
\hline 05.00 & $60 \mathrm{~m}$ & 29.11 & 90.25 & 38.56 \\
13.00 & & 32.33 & 71.16 & 42.83 \\
21.00 & & 29.47 & 90.31 & 36.49 \\
05.00 & \multirow{2}{*}{$120 \mathrm{~m}$} & 29.22 & 90.17 & 39.04 \\
13.00 & & 30.61 & 81.18 & 40.28 \\
21.00 & & 29.40 & 87.93 & 38.77 \\
\hline
\end{tabular}




\section{Results and Analysis}

Table 3. Starter Period Broiler Chicken Behavior for 24 Hours

\begin{tabular}{|c|c|c|c|c|c|c|c|c|c|c|}
\hline \multirow[t]{4}{*}{ Length } & \multicolumn{10}{|c|}{ Behavior } \\
\hline & \multicolumn{4}{|c|}{ Heat Production } & \multicolumn{6}{|c|}{ Heat Loss } \\
\hline & \multicolumn{2}{|c|}{ Walking } & \multicolumn{2}{|c|}{ Eating } & \multicolumn{2}{|c|}{ Resting } & \multicolumn{2}{|c|}{ Stretching } & \multicolumn{2}{|c|}{ Drinking } \\
\hline & $\begin{array}{l}\text { Frequen } \\
\text { cy } \\
\text { (times) }\end{array}$ & $\begin{array}{l}\text { Duratio } \\
\mathrm{n} \\
\text { (minut } \\
\text { e) }\end{array}$ & $\begin{array}{c}\text { Frequen } \\
\text { cy } \\
\text { (times) }\end{array}$ & $\begin{array}{c}\text { Duratio } \\
\mathrm{n} \\
\text { (minute) }\end{array}$ & $\begin{array}{c}\text { Frequen } \\
\text { cy } \\
\text { (times) }\end{array}$ & $\begin{array}{c}\text { Duratio } \\
\mathrm{n} \\
\text { (minut } \\
\text { e) }\end{array}$ & $\begin{array}{c}\text { Frequen } \\
\text { cy } \\
\text { (times) }\end{array}$ & $\begin{array}{c}\text { Duratio } \\
\mathrm{n} \\
\text { (minut } \\
\text { e) }\end{array}$ & $\begin{array}{c}\text { Frequen } \\
\text { cy } \\
\text { (times) }\end{array}$ & $\begin{array}{l}\text { Duratio } \\
\mathrm{n} \\
\text { (minut } \\
\text { e) }\end{array}$ \\
\hline $60 \mathrm{~m}$ & 4.62 & 4.59 & 4.91 & 4.90 & 3.93 & 4.00 & 3.68 & 4.44 & 4.84 & 4.56 \\
\hline $120 \mathrm{~m}$ & 4.37 & 4.40 & 4.09 & 4.09 & 4.93 & 4.68 & 5.31 & 4.56 & 4.16 & 4.43 \\
\hline
\end{tabular}

Table 3 shows that chickens raised in a $120 \mathrm{~m}$ cage increased the frequency and duration of resting and stretching without changing or increasing the frequency and duration of drinking due to higher ammonia stress. This is presumably because longer cages have a higher temperature (Bailey, 1990) which is supported by Pichard (1995) stating that rest is conducted when consumption needs are met or the temperature is high. High body weight and growth rate also make chickens tend to have more rest (Rokhman, 2013). In the $120 \mathrm{~m}$ cage, rests are longer but less frequent. This is allegedly caused by a high level of stress or illness. This is in accordance with the observation of Dewi (2005) which shows a decrease in broiler locomotion (the activity of moving and playing around). Chickens in the $120 \mathrm{~m}$ cage show a higher frequency and duration of stretching, which is presumably caused by oxidative stress which provokes the chickens to attempt to remove heat from the body. This is in line with the opinion of Lin et al. (2006) which states that oxidative stress results from heat stress and disrupts the metabolic system of the chicken. The frequency of stretching is higher in the $120 \mathrm{~m}$ cage due to the fluctuating heat which causes stretching to reduce body heat. This is in accordance with the opinion of Hanim (1997) which states that chickens will try to compensate for the decreased ability to dispose of heat when facing heat stress through increasing physiology responsible for the heat dissipation process which also directly reduces heat production.

Without increasing the duration or the frequency of drinking is allegedly due to broiler sufficient adjustment to compensate for the inefficiency of heat loss. In other words, the temperature change has not reached a high level of extremity resulting in no increase in water consumption. Zurriyati and Dahono (2013) stated that increasing water consumption is an effort to reduce body heat due to extreme temperature changes. According to Rokhman (2013), the average water consumption at hot ambient temperature is 18.33 . 
Chickens raised in a $120 \mathrm{~m}$ cage will lower heat production by reducing the frequency and duration of eating and walking. According to the European Commission (2000), this is presumably caused by the accumulation of ammonia and the circulation of heat and air velocity in longer cages which cause chickens to experience heat stress. According to Austic (1985), the decrease of appetite in chickens residing in a $120 \mathrm{~m}$ cage is due to high ambient temperature. According to May and Lott (2001), appetite decrease occurs to prevent heat accumulation in the body which will decrease body weight. Renata et al. (2018) stated that high ammonia level causes the oxygen level to decrease. This will lead to a decrease in body oxygen which causes the chickens to be exposed to heat stress and prompt them to stabilize their body temperature. This was confirmed by Puspani et al. (2008), stating that the smaller the difference in body temperature and ambient temperature, the harder it is to release body heat which in turn causes stress. This is a common occurrence in the $120 \mathrm{~m}$ cage, presumably because the amount of heat produced by muscle activity and tissue metabolism is proportional to the amount of heat lost through environmental factors. This is in accordance with the opinion of Sulistyoningsih (2003), which states that the total heat generated by muscle activity is proportional to the amount of heat circulated by the environment. This is also known as zone thermoneutrality, in which there is little or no change in heat production.

\section{Conclusion}

The results showed that chickens kept in a longer cage would show behavioral responses that represented increased heat loss and reduced heat production.

\section{References}

[1] Austic, R. E. 1985. Feeding Poultry in Hot and Cold Climates, in Stress Physiology in Livestock, Vol. III. In: M.K. Yousef (Ed). CRC. Press, Inc, Boca Raton, Florida.

[2] Bailey, R. A., J. Kurnert and Martin, R.J. 1990. Some comments on gerechte designs. J. Agro and Crop Sci. $165: 121-130$.

[3] European Commission. 2000. Health and consumer protection directorate-general: The welfare of chickens kept for meat production (Broilers). Report of The Scientific Committee on Animal Health and Animal Welfare.

[4] Hanim, C. 1997. Manejemen menghadapi stres panas pada ayam pedaging. Poultry Indonesia. $208: 10-12$

[5] Haryadi, 1995. Pengaruh amonia terhadap kesehatan hewan. Poultry Indonesia, Majalah Ekonomi Indonesia dan Teknologi Perunggasan Populer, Jakarta. 
[6] Lambey, L. J., Noor, R.R., Manalu, W., and Duryadi, D. 2011. Tingkah laku menetas piyik burung weris (Gallirallus philipensis) dan burung dewasa dalam penangkaran. J. Veteriner $16(2): 274-282$

[7] Lin, H., Decuypere, E., and Buyse, J. 2006. Acute heat stress induces oxidative stress in broiler chickens. Comp. Biochem. Physiol. A. Mol. Integr. Physiol. 144: 11-17.

[8] May, J., and Lott, B.D. 1992. Feed and water consumption patterns of broiler at high environmental temperatures. Poultry Sciences. 71: 331-336.

[9] May, J., and Lott, B.D. 2001. The effect of environmental temperature on growth and feed conversion of the broiler to 21 days of age. Poultry Sciences. 79: 669-671.

[10] Murtidjo, B. A. 1987. Pedoman Beternak Ayam Broiler. Kanisius, Yogyakarta.

[11] Pritchard, D. C. 1995. The language of light. In: Lighting. Longman, Harlow, pp. 1-14.

[12] Puspani, E., Nuriyasa, I.M., Putra, W.A.A.P., and Candrawati, D.P.M.A. 2008. Pengaruh tipe kandang dan kepadatan ternak terhadap tabiat makan ayam pedaging umur 2-6 minggu. Majalah Ilmiah Peternakan. 11(1): 7- 11.

[13] Renata.,Sarjana, T.A,. and Kismiati, S. 2018. Pengaruh zonasi dalam kandang closed house terhadap kadar amonia dan dampaknya pada kualitas daging broiler di musim penghujan. J. Ilmu-ilmu Peternakan. 28(3): 183 - 191.

[14] Rokhman, A. 2013. Respon Tingkah Laku Ayam Broiler Pada Suhu Kandang Yang Berbeda. Fakultas Peternakan. Institut Pertanian Bogor, Bogor. (Skripsi Sarjana Peternakan).

[15] Sulaibah, S., Sarjana, T.A., and Muwarni, S. 2019. Pengaruh perbedaan panjang kandang dan zona penempatan di dalam closed house terhadap total leukosit dan diferensial leukosit ayam broiler. J. Agromedia 37(1): 86-92

[16] Sulistyoningsih, M. 2003. Pengaruh temperatur lingkungan terhadap ayam broiler. Majalah Ilmiah Lontar 17(1): 67 - 82

[17] Tamzil, M. H. 2014. Stres panas pada unggas: Metabolisme, akibat dan upaya penanggulangannya. Wartazoa 24 (2): 57-66.

[18] Zurriyati, Y., and Dahono. 2013. Respon fisiologis dan evaluasi karkas ayam broiler terhadap suhu pemeliharaan dingin. Seminar Nasional Teknologi Peternakan dan Veteriner. Medan, 3 - 4 September 2013. Puslitbang Peternakan. 586-591. 